\title{
Nkx2.5 Based Ventricular Programming of Murine ESC-Derived Cardiomyocytes
}

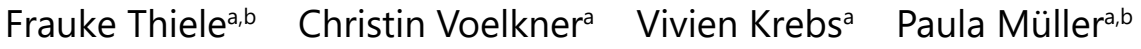 \\ Julia Jeannine Jung ${ }^{a, b} \quad$ Christian Rimmbach ${ }^{a, b}$ Gustav Steinhoffa,b Thomas Noack ${ }^{c}$ \\ Robert Davida ${ }^{a, b}$ Heiko Lemcke ${ }^{a, b}$
}

aDepartment of Cardiac Surgery, Reference and Translation Center for Cardiac Stem Cell Therapy (RTC), University Medicine Rostock, Rostock, Germany, baculty of Interdisciplinary Research, Department Life, Light \& Matter, University Rostock, Rostock, Germany, 'Oscar-Langendorff-Institute for Physiology, University Medicine Rostock, Rostock, Germany

\section{Key Words}

Cardiovascular forward programming • Nkx2.5 • Ventricular subtype identity • PSCs

\begin{abstract}
Background/Aims: The availability of truly maturated cardiomyocytic subtypes is a major prerequisite for cardiovascular cell replacement therapies. Pluripotent stem cells provide a suitable source for the development of new strategies to overcome enormous hurdles such as yield, purity and safety of in vitro generated cells. Methods: To address these issues, we have refined existing forward programming protocols by combining forced exogenous overexpression of the early cardiovascular transcription factor Nkx2.5 with a $\alpha \mathrm{MHC}$-promoterbased antibiotic selection step. Additionally, we applied small molecules such as ascorbic acid to enhance cardiomyogenic differentiation efficiency. Subsequently, we evaluated the cell fate of the resulting cardiomyocytes on the mRNA as well as protein levels. The latter was performed using high-resolution confocal microscopy. Furthermore, we examined the response of the cells' beating activities to pharmacological substance administration. Results: Our results reveal an apparent influence of Nkx2.5 on the cell fate of ESC-derived cardiomyocytes. Resulting single cells exhibit characteristics of early ventricular cardiomyocytes, such as sarcomeric marker expression, spontaneous beating frequency, and distinct L-type calcium channel occurrence. Conclusion: Therefore, we demonstrate cardiovascular subtype forward programming of ESCs using a combination of transcription factors along with small molecule administration. However, our findings also underline current assumptions, that a terminal maturation of PSC derived cardiomyocytes in vitro is still an unsolved problem which urgently needs to be addressed in the field.




\section{Cellular Physiology Cell Physiol Biochem 2019;53:337-354 \\ \begin{tabular}{ll|l} 
and Biochemistry & $\begin{array}{l}\text { DOl: 10.33594/000000142 } \\
\text { Published online: } 3 \text { August } 2019\end{array}$ & $\begin{array}{l}\text { O } 2019 \text { The Author(s). Published by } \\
\text { Cell Physiol Biochem Press GmbH\&Co. KG }\end{array}$ \\
\cline { 2 - 3 }
\end{tabular} \\ Thiele et al.: Nkx2.5 Based Ventricular Programming}

\section{Introduction}

The complex organization of the mammalian four-chambered heart requires the generation of several muscle and non-muscle cell types during embryonic development. This comprises cardiomyocytes (CM) of left and right atria as well as left and right ventricles, conduction system, pacemaker, vascular smooth muscles, endo- and epicardial cells $[1,2]$. The definite cell fate is achieved through spatiotemporally stringent molecular regulations. Previous findings from work on mouse embryogenesis suggest a $\mathrm{Nkx} 2.5^{+} / \mathrm{Hcn} 4^{+}$cell

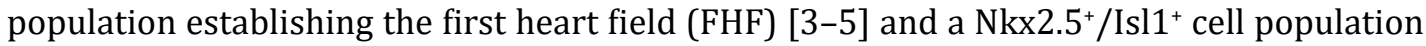
establishing the second heart field (SHF) $[6,7]$ which would evolve independently, originating from a mesodermal cardiovascular MesP1 $1^{+} / \mathrm{Flk} 1^{+}$progenitor [8-10]. The pivotal role of the homeobox protein $\mathrm{Nkx} 2.5$ as a transcription factor (TF) regulating cardiogenic development is also evident from its highly conserved structural and functional occurrence across species $[11,12]$. Homologues of Nkx2.5 are present in the contracting pharynx of the nematode Caernorhabditis elegans [13], crucial for the development of the tubular heart in the common fruit fly Drosophila melanogaster $[14,15]$ and promote myocardial development in zebrafish and Xenopus embryos [16, 17]. So far, little is known about the precise pathways underlying spatiotemporal regulations to form the entire heart and particularly specific CM subtype differentiation. Nonetheless, it is known that one consequence of false embryonic development are congenital heart defects (CHD) present at birth due to malformation of heart structures $[18,19]$. Dysregulation of the involved TFs such as Nkx2.5 play a decisive role in their pathogenesis $[20,21]$. Besides, potential underlying genetic polymorphisms affecting Nkx2.5 expression are discussed, at present [21]. Moreover, it has been demonstrated that downstream factors of Nkx2.5 such as Isl1 [22] or Bmp2 and Smad1 [23] have an impact on CM subtype identity in mutant mouse models.

So far, diverse strategies aimed to comprehend embryonic heart development to reproduce distinct cardiovascular cell types. However, an efficient in vitro cardiogenic differentiation of pluripotent stem cells (PSCs) towards mature CMs is an unfulfilled aim. Moreover, terminal maturation is of great importance as a direct application of undifferentiated PSCs is unfeasible due to their high potential to form teratoma in vivo [24, 25]. In addition, transplantation of a heterogeneous CM mixture could induce arrhythmias [26]; thus, purification resulting in homogenous CM subtype populations is an indispensable prerequisite for clinically relevant scenarios. Moreover, it should be considered that induced pluripotent stem cell (iPSC) lines typically reveal a highly heterogeneous gene expression profile exceeding that of embryonic stem cells (ESCs) [27-29], which further impedes a reliably unified differentiation model of iPSCs.

We therefore investigated and improved existing murine ESC forward programming protocols $[8,30]$ to evaluate the potential of $\mathrm{Nkx} 2.5$ for in vitro generation of cardiomyocytic subtypes. By combining a forced exogenous overexpression of Nkx2.5 [30] and a $\alpha \mathrm{MHC}$ promotor-based antibiotic selection [31], we achieved a pure $\alpha \mathrm{MHC}^{+}$cell population with augmented maturation toward early ventricular CMs.

\section{Materials and Methods}

Culture of murine ECSS

W4 murine embryonic stem cells (mESCs) [32] were cultured in DMEM supplemented with $15 \%$ FBS Superior (Biochrom AG, Germany), 1 \% Cell Shield $®$ (Minerva Biolabs GmbH, Germany), $100 \mu \mathrm{M}$ nonessential amino acids, $1000 \mathrm{U} / \mathrm{mL}$ leukemia inhibitory factor (Phoenix Europe GmbH, Germany) and $100 \mu \mathrm{M}$ $\beta$-mercaptoethanol (Sigma-Aldrich $\mathrm{GmbH}$, Germany) at $37{ }^{\circ} \mathrm{C}, 5 \% \mathrm{CO}_{2}$ and $20 \% \mathrm{O}_{2}$.

Undifferentiated mESCs were co-cultured for at least seven days on inactivated murine embryonic fibroblasts SNL 76/7 (STO cell line). Afterwards, mESCs were removed from the SNL feeders using collagenase IV (1 mg/mL) and accutase (400-600 units/mL) as previously described [33]. Clones were subsequently cultured under antibiotic selection (W4 $\alpha \mathrm{MHC}: 250 \mu \mathrm{g} / \mathrm{mL}$ hygromycin; W4 $\alpha \mathrm{MHC}$ hNkx2.5: 


\section{Cellular Physiology Cell Physiol Biochem 2019;53:337-354

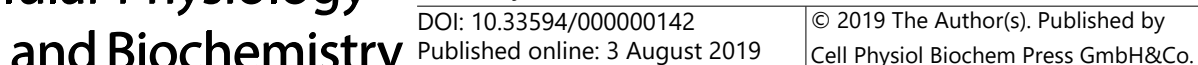 \\ Thiele et al.: Nkx2.5 Based Ventricular Programming}

$250 \mu \mathrm{g} / \mathrm{mL}$ hygromycin and $10 \mu \mathrm{g} / \mathrm{mL}$ blasticidin) on gelatine coated culture plates to ensure a feeder free and pure cell population.

\section{Generation of Nkx2.5 overexpressing murine ESCS}

The mESCs were transfected with a pGK-hygro $\alpha$ MHC-puromycin cassette previously described with subsequent clone selection [31, 34]. The resulting W4 $\alpha$ MHC ESCs were detached with trypsin for 3 min at $37^{\circ} \mathrm{C}$, centrifuged and counted in respective standard growth medium. For the second transfection with the human Nkx2.5 cDNA, a commercially available Full-ORF-Expression Clone (Clone-Nr.: OCAAo5051H0157pEF-DEST51) purchased from Imagenes (Berlin, Germany) was used. For this transfection step, cells were seeded in a density of $5.4 \times 10^{5}$ per $\mathrm{cm}^{2}$ in a TTP cell culture plate. $6 \mathrm{~h}$ after seeding, the cells were transfected using jetPEI ${ }^{\circledR}$ DNA transfection reagent (Polyplus transfection ${ }^{\circledR}$, USA) according to the manufacturer's instructions using $20 \mu \mathrm{g}$ nucleic acid per $5 \times 10^{6}$ cells. The first medium change was performed $24 \mathrm{~h}$ after transfection with the addition of respective antibiotics. Subsequently, clones were picked and cultured under antibiotic selection (W4 $\alpha$ MHC: $250 \mu \mathrm{g} / \mathrm{mL}$ hygromycin; W4 $\alpha$ MHC hNkx2.5: $250 \mu \mathrm{g} / \mathrm{mL}$ hygromycin and $10 \mu \mathrm{g} / \mathrm{mL}$ blasticidin).

\section{Cardiovascular differentiation of mECSs}

Ventricular differentiation of mESCs was performed in cardiogenic differentiation medium, containing IBM (Iscove's Basal Medium, Biochrom AG, Germany) supplemented with $10 \%$ FBS Superior, 1 \% Cell Shield ${ }^{\circledR}, 100 \mu \mathrm{M}$ non-essential amino acids, $450 \mu \mathrm{m}$ 1-thioglycerol (Sigma-Aldrich GmbH, Germany), $213 \mu \mathrm{g} / \mathrm{mL}$ ascorbic acid (Sigma-Aldrich GmbH, Germany) and respective antibiotics (W4 $\alpha$ MHC: $250 \mu \mathrm{g} /$ mL hygromycin; W4 $\alpha$ MHC hNkx2.5: $250 \mu \mathrm{g} / \mathrm{mL}$ hygromycin and $10 \mu \mathrm{g} / \mathrm{mL}$ blasticidin). Differentiation was initiated by hanging-drop culture for two days at $37{ }^{\circ} \mathrm{C}, 5 \% \mathrm{CO}_{2}$ and $20 \% \mathrm{O}_{2}$. Therefore, 400 cells per drop were plated on the cover of a square petri dish. Afterwards, formed embryoid bodies (EBs) were cultured for four days in suspension culture, whereby they were regularly shaken. From day 7 on, cells were split using two different oxygen concentrations $\left(1 \% \mathrm{O}_{2}\right.$ and $\left.20 \% \mathrm{O}_{2}\right)$ and were thereafter examined with regard to their spontaneous beating activity and quantity. Qualitative analysis of spontaneously beating activity was performed by seeding at average $10 \mathrm{EBs}$ per single well of a gelatin-coated 24 well dish with subsequent counting of resulting beating areas per EB for 14 days.

The optimal time point for the $\alpha \mathrm{MHC}$-antibiotic selection step was evaluated by seeding at average 10 EBs per single well of a gelatin coated 24 well dish and subsequent treatment with $2 \mu \mathrm{g} / \mathrm{mL}$ puromycin on day 7, 9, 11, 13 or 15 of differentiation. Single cells were obtained through dissociation four days after puromycin treatment with collagenase IV and accutase and counted at day 12 of differentiation.

\section{Isolation of neonatal cardiomyocytes}

Neonatal CMs were obtained from 1-2 day old NMRI mice and isolated using Pierce primary CM isolation kit according to the manufacturer's instructions (Thermo Fisher Scientific). The whole isolation process has been described previously [35]. CMs were cultivated in DMEM supplemented with $10 \%$ FBS and $1 \% \mathrm{P} / \mathrm{S}$ (all Pan Biotech) and grown on $0.1 \%$-gelatine (Sigma-Aldrich) coated surfaces.

\section{RNA isolation}

Isolation of total RNA from undifferentiated mESC clones was performed using NucleoSpin® RNA isolation kit (Macherey-Nagel, Germany) and from cardiogenic derived single cells at day 25 of differentiation using NucleoSpin ${ }^{\circledR}$ RNA isolation kit XS (Macherey-Nagel, Germany) following the manufacturer's instructions. Purity and concentration were analyzed with NanoDrop 1000 Spectrophotometer (Thermo Fisher Scientific Inc., USA).

\section{Reverse transcription}

Synthesis of first strand cDNA from aforementioned total-RNA was performed using the RevertAid $\mathrm{H}$ Minus First Strand cDNA Synthesis Kit (Thermo Fisher Scientific Inc., USA) following the manufacturer's instructions. The reverse transcription was performed applying the Oligo(dT)18 primer. The reaction was conducted using the MJ Mini ${ }^{\mathrm{TM}}$ thermal cycler (Bio-Rad Laboratories GmbH, Germany). 


\section{Cellular Physiology Cell Physiol Biochem 2019;53:337-354 \\ \begin{tabular}{ll|l} 
and Biochemistry $10.33594 / 000000142$ & Published online 3 August 2019 & Cell The Author(s). Published by \\
\end{tabular} \\ Thiele et al.: Nkx2.5 Based Ventricular Programming}

Quantitative real-time polymerase chain reaction

qPCR was performed using the StepOnePlus ${ }^{\text {TM }}$ Real-Time PCR System (Applied Biosystems, Germany) with the following program (StepOne ${ }^{\mathrm{TM}}$ Software Version 2, Applied Biosystems, Germany): start at $50^{\circ} \mathrm{C}$ for $2 \mathrm{~min}$, initial denaturation at $95^{\circ} \mathrm{C}$ for $10 \mathrm{~min}$, denaturation at $95^{\circ} \mathrm{C}$ for $15 \mathrm{~s}$ and annealing/elongation at 60 ${ }^{\circ} \mathrm{C}$ for 1 min with 40 cycles. A qPCR reaction consists of TaqMan ${ }^{\circledR}$ Universal PCR Master Mix (Thermo Fisher Scientific Inc., USA), respective TaqMan ${ }^{\circledR}$ Gene Expression Assay, UltraPure ${ }^{\mathrm{TM}}$ DNase/RNase-Free Distilled Water (Thermo Fisher Scientific Inc., USA) and $10 \mathrm{ng}$ of the respective cDNA. Analysis and evaluation of gene expression profiles were performed using the $\Delta \Delta \mathrm{Ct}$ method for relative quantifications. Therefore, mean values of target genes (cTnnT2: Mm01290256_m1; Fut4: Mm00487448_s1; Gja1: Mm00439105_m1; Hcn4: Mm01176086_m1; Isl1: Mm00517585_m1; MesP1: Mm00801883_m1; Myh6: Mm00440359_m1; Myl2: Mm00440384_m1; Nanog: Mm02019550_s1; Pou5f1: Mm00658129_gH;) were normalized to the mean values of the housekeeping genes Hprt (Mm00446968_m1) and Polr2a (Mm00839493_m1) and relative considered to a respective control probe. All qPCR TaqMan ${ }^{\circledR}$ Gene Expression Assays were purchased from Thermo Fisher Scientific Inc., USA.

\section{Immunohistochemistry}

Visualization of pluripotent expression pattern of mESCs. W4 mESC clones were seeded on cover slips and fixed after $48 \mathrm{~h}$ with $4 \%$ formaldehyde and incubated afterwards with $50 \mathrm{mM}$ ammonium chloride. Cells were permeabilized with $0.2 \%$ Triton X-100 and blocked with $1 \%$ BSA (in PBS). All antibodies were incubated in blocking solution containing $0.01 \%$ saponin (Sigma-Aldrich GmbH, Germany) in $1 \%$ BSA, primary antibodies for $1 \mathrm{~h}$ at RT and secondary antibodies for $40 \mathrm{~min}$ at RT. Antibody staining was performed one after another to avoid cross-reactivity. The following antibodies were used for mESC clones, primary antibodies: Nkx.2.5 (Sc8697, Santa Cruz Biotechnology Inc., USA; 1:100), Oct4 (ab19857, Abcam, UK; 1:200), and secondary antibodies: Alexa Fluor ${ }^{\circledR} 568$ donkey anti-goat (A-11057, Life Technologies, USA, 1:300) and Alexa Fluor ${ }^{\circledR} 568$ goat anti-rabbit (A11011, Life Technologies, USA, 1:300). Additionally, the cells were counterstained with Phalloidin-FITC (ALX-350-268-MC01, Enzo Life Science, Inc., USA, 1:500). Samples were mounted with Fluoroshield ${ }^{\mathrm{TM}}$ with DAPI (Sigma-Aldrich, Germany) for nuclei staining. Images were performed using ELYRA PS.1 LSM 780 confocal microscope (Carl Zeiss, Germany) and ZEN2011 software (Carl Zeiss, Germany).

Visualization of cardiogenic-derived single cells. Cardiogenic-derived single cells were treated in as described above. The following antibodies were used for single cells, primary antibodies: Cx43 (Connexin 43; Sc9059, Santa Cruz Biotechnology, Inc., USA, 1:100), cTnT (cardiac troponin T; ab115134, Abcam, UK; 1:100), HCN4 (; APC-052, Alomone labs, Israel; 1:100), Myh6 (Myosin heavy chain $\alpha$; ab15, Abcam, UK; 1:100), Myh7 (Myosin heavy chain $\beta$; M8421, Sigma-Aldrich GmbH, Germany; 1:500), $\alpha$-actinin (ab9465, Abcam, UK; 1:100), secondary antibodies: Alexa Fluor ${ }^{\circledR} 568$ donkey anti-goat (A11036, Life Technologies, USA; 1:300), Alexa Fluor ${ }^{\circledR} 647$ goat anti-mouse (A21235, Life Technologies, USA, 1:300), Alexa Fluor ${ }^{\circledR} 488$ donkey anti-rabbit (A21206, Life Technologies, USA; 1:300) and Alexa Fluor ${ }^{\circledR} 568$ goat anti-rabbit (A11011, Life Technologies, USA; 1:300). Samples were mounted with Fluoroshield ${ }^{\mathrm{TM}}$ with DAPI for nuclei staining. Images were performed using the superresolution technology structured illumination microscopy (SIM). Therefore, sample images were recorded with the 100x alpha 1.46 Plan Apochromat ${ }^{\circledR}$ (Carl Zeiss) objective with oil immersion. Z-stacks were recorded in SIM mode with a 16 bit depth at 5 angles, with averaging 4; 23 $\mu \mathrm{m}$ grid was applied for 405 laser line, $34 \mu \mathrm{m}-488,42 \mu \mathrm{m}-561,51 \mu \mathrm{m}-633$. The obtained SI raw datasets were computationally reconstructed by ZEN software and presented at alignment of Maximum projections.

\section{Live cell imaging}

Live cell imaging was performed using ELYRA PS.1 LSM 780 confocal microscope and ZEN2011 software (Carl Zeiss). Cells were incubated during observation at $37^{\circ} \mathrm{C}$.

Analysis of beating frequencies. The spontaneous beating frequency of cardiogenic-derived single cells was analyzed at day 25 of differentiation. Therefore, cells were plated after dissociation on gelatine coated 24 well plates and kept in differentiation culture until observation. The recording was performed using 10fold optical magnification and 20 images per second. After recording, mean region of interest (mROI) was specified and the varying light intensity at the mROI determined. The displayed peaks equates to a beat of the cell. 


\section{Cellular Physiology Cell Physiol Biochem 2019;53:337-354 \\ \begin{tabular}{ll|l} 
and Biochemistry & $\begin{array}{l}\text { DOl: 10.33594/000000142 } \\
\text { Published online: } 3 \text { August } 2019\end{array}$ & $\begin{array}{l}\text { O } 2019 \text { The Author(s). Published by } \\
\text { Cell Physiol Biochem Press GmbH\&Co. KG }\end{array}$ \\
\cline { 2 - 3 }
\end{tabular} \\ Thiele et al.: Nkx2.5 Based Ventricular Programming}

Physiological investigations. Using the aforementioned method for the determination of spontaneous beating frequencies, cell characteristics were examined under different physiological conditions. However, only spontaneous beating single cells could be analyzed in terms of their physiological behavior. Single cells without own spontaneous beating were not included in the analysis.

Cardiogenic-derived single cells were evaluated under administration of the following reagents: Noradrenaline $(1 \mu \mathrm{M})$, Acetylcholine $(10 \mu \mathrm{M})$, Mibefradil $(10 \mu \mathrm{M})$, Verapamil $(10 \mu \mathrm{M})$, Tetrodotoxin $(10$ $\mu \mathrm{M})$ and potassium rich extracellular fluid (20 mM). First, beating frequency was determined as baseline $(\mathrm{t} 0)$. Second recording comprised a period of 2 minutes to include 2 time points: $10 \mathrm{~s}$ after application ( $\mathrm{t} 1$ ) and 1 min after application ( $\mathrm{t} 2$ ) of the respective reagent. The closing record was performed 5 min after application ( $\mathrm{t} 3$ ). Findings represent the differences between the respective time points after application to the baseline beating frequency.

\section{Statistics}

Statistical analyses were performed using OriginPRO 2016G (OriginLab Corporation, USA). All data are reported as mean \pm SEM. Student's t-test and One Way Analysis of Variance (ANOVA) were performed for multiple comparisons with Bonferroni post hoc test. $\mathrm{P}<0.05$ was considered statistically significant.

\section{Results}

\section{Generation of stably Nkx2.5 overexpressing mES cells}

To achieve a ventricular differentiation of mESCs, the lineage specific TF Nkx2.5 of human origin was used for its better traceability in murine cells. An exogenous overexpression was achieved by introducing pEF-DEST51-hNkx2.5 in stably Mhy6-puro/PGKhygro containing mESCs [31]. In order to maintain integrity of both plasmids, selection pressure was applied using hygromycin and blasticidin in respective concentrations (see methods). Confirmation of Nkx2.5 overexpression (Fig. 1B) and pluripotency of the cells (Fig. 1A, C) were performed after continuous cultivation with leukemia inhibitory factor (LIF) [36, 37] and an intermediate co-cultivation for seven days with mitotically inactivated murine embryonic fibroblasts derived from the line SNL 76/7 [38]; referred to as day 0 of differentiation. As demonstrated by qPCR (Fig. 1A) and immunostaining (Fig. 1C), overexpression of Nkx2.5 did not significantly influence the expression of typical pluripotency markers (Oct4, Nanog, Fut4) of mESCs. Moreover, analysis of early cardiac markers (MesP1, Isl1) revealed that Nkx2.5 overexpression alone is not sufficient to induce cardiogenic differentiation. Furthermore, mESCs retained an active cell cycle, as evident from the appearance of pro-, ana- and telophase of the mitotic phase (data not shown).

\section{Optimization of cell culture conditions}

In order to achieve the maximum cell yield, the protocol by Jung et al. [34] was modified to promote the differentiation into a ventricular cell subtype. Therefor ascorbic acid (AA) was additionally supplied with the medium to promote cardiogenesis [39, 40]. In addition, the influence of oxygen was examined by modulation of oxygen supply after EB formation. At $20 \%$ oxygen, an increased beating activity, starting at day 8, was observed during differentiation - yet, without a significant difference between the three tested specimens (Fig. 2A). Under $1 \%$ oxygen supply, cells showed a similar beating behavior (Fig. 2B), although the Nkx2.5 overexpressing clone displayed slightly more beating areas per EB over the time which became statistically significant from day 12 onward. However, the time point of $\alpha$ MHC-selection had a remarkable impact on the single cell amount at day 25 of differentiation (Fig. 2C, D). For this purpose, experiments with different starting time points of antibiotic (puromycin) treatment were tested, particularly day 7, 9, 11, 13 and 15 of differentiation under $1 \%$ and $20 \% \mathrm{O}_{2}$. These revealed that puromycin selection under both oxygen conditions initiated at day 7 of differentiation, followed by an additional dissociation step on day 11 , led to a $\sim 10$-fold $\left(20 \% \mathrm{O}_{2}\right)$ larger population showing $\alpha$-MHC promoter activity in the Nkx2.5 overexpressing clone derived cells as compared to controls (Fig. 2C) as 


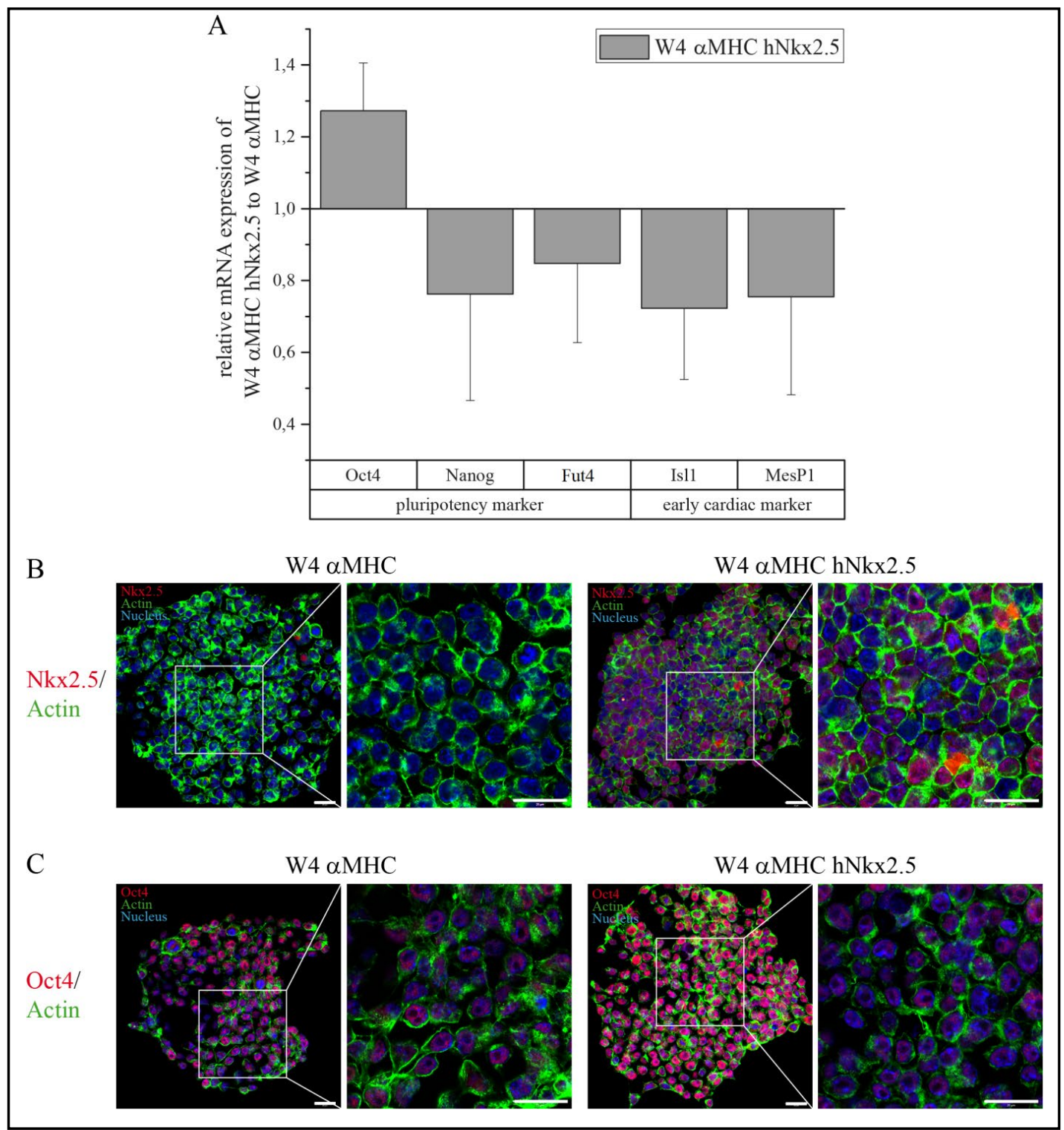

Fig. 1. Description of the original mES cell state: Marker expression of W4 $\alpha$ MHC and W4 $\alpha$ MHC hNkx2.5 clones on day 0 of differentiation. (A) Relative expression of pluripotency and early cardiac markers performed by qPCR. Values relativized to W4 $\alpha$ MHC (set: 1 ). Values are presented as mean \pm SEM; $n=3$; statistic was performed as t-test. (B) Confirmation of Nkx2.5 overexpression on protein level using immunostaining of actin (green) and exogenous Nkx2.5 (red), scale bar: $20 \mu \mathrm{m}$. (C) Confirmation of pluripotency on protein level using immunostaining of actin (green) and Oct4 (red), scale bar: $20 \mu \mathrm{m}$.

well as $\sim 5$-fold larger population under $1 \%$ oxygen (Fig. 2D). The number of CMs obtained from one input PSC was $\sim 8$ times higher in cells overexpressing Nkx2.5 ( $\alpha$ MHC $-\mathrm{Nkx} 2.5^{+}$vs. $\alpha$ MHC: 0.05 vs. 0.0063 ). Furthermore, to determine the percentual content of CM-like cells within these cultures, immunofluorescent stainings of $\alpha$-actinin (green) and troponin T (red) at day 25 of differentiation were performed (Fig. 2E). Quantitative analysis revealed that $\sim 98 \%$ of all cells in the culture were positive for these cardiac markers (Table 1). Moreover, fluorescence microscopy also demonstrated well-organized sarcomere structures in Nkx2.5 overexpressing CMs (Fig. 2F).

On the basis of these overall data, subsequent experiments were performed under 20 $\%$ oxygen conditions from day 0 of differentiation onward. Moreover, murine embryonic 


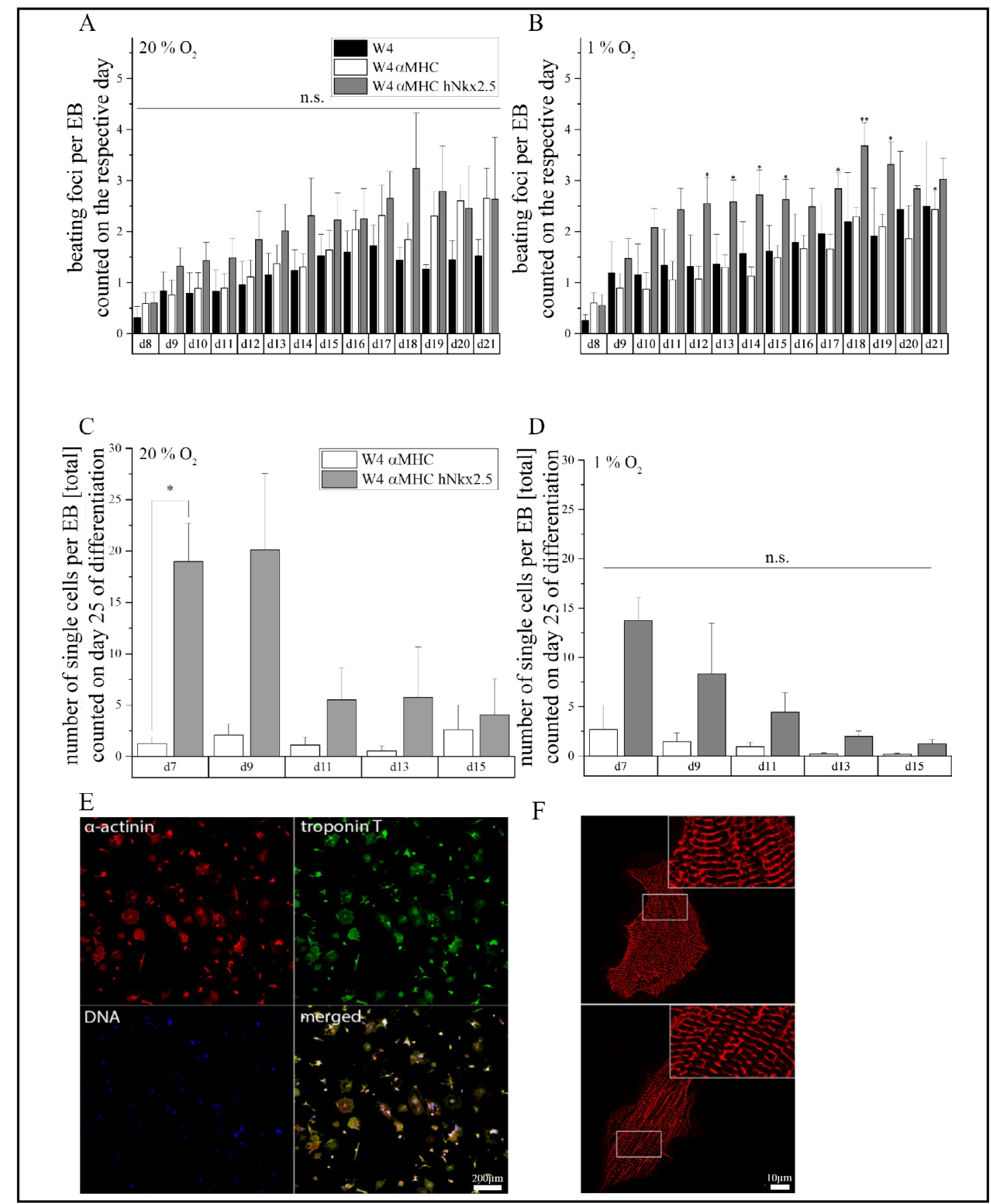

Fig. 2. Optimization process during cardiogenic differentiation: Quantitative determination of spontaneously beating areas per EB (n=7 (d8-d17), n=3 (d18-d21)) under $20 \% 02$ (A) and $1 \% 02$ oxygen conditions. Quantitative determination of the optimal time point to initiate antibiotic $\alpha$ MHC-selection with respect to maximum cell yields under $20 \% 02$ (C) and $1 \% 02$ oxygen conditions (D); therefore cells were treated on different time points with puromycin and single cell number was subsequently determined at day 25 of differentiation $(n=3)$. Values are presented as mean $\pm S E M$; statistics were performed as multiple comparison of mean within one specimen to compare time points - no significance calculated; and t-test to compare both specimen within one time point; ${ }^{*} \mathrm{p} \leq 0.05$. (E, F) Immunofluorescent stainings for $\alpha$-actinin (green) and troponin T (red) of antibiotic selected and Nkx2.5 programmed cells at day 25 of differentiation. Nuclei are stained with DAPI (blue). Almost all cells in the culture are double-positive for the cardiac markers. (G) Representative immunoflourescent images of Nkx2.5 programmed cells, showing well-organized sarcomere structures. 
stem cells (W4), without any genetic manipulation confirm the functionality of $\quad \alpha \mathrm{MHC}$ selection methodology, as these cells entirely died during antibiotic treatment.

Generally, programmed

Nkx.5 control cells gave rise to comparable cell shapes (Fig. 3 ), whereby a distinction can be made between three morphologically different groups of beating cells: (i) spindle- and spider-like cells [34], (ii) large round and large square-shaped cells and (iii) an undefined cell type including large longitudinal and small round cell shapes. Spindle cells are characterized by a thin spindle-shape with two opposed extensions with an approximately cell size of $16 \times 66 \mu \mathrm{m}(\mathrm{n}=12)$ while spider cells possess five or more extensions in all directions as described before by Jung et al., 2014 [40]. Moreover, the spider cells had a bigger size $(56 \times 88 \mu \mathrm{m})(\mathrm{n}=3)$ while both cell types displayed a raised cell body. The second morphological group is defined by a flat round or squared shape, with or without extensions, they are the largest population with a cell size of approximately $94 \times 118 \mu \mathrm{m}$ $(n=9)$. Cells which do not match the aforementioned categories were named as undefined cells, this includes beating cells which had adopted a small rounded shape $(23 \times 31 \mu \mathrm{m}$; $\mathrm{n}=7$ ) and underwent apoptosis within the next week. Moreover, the group of undefined cells contained larger longitudinal specimen with a size of approximately 34 x $59 \mu \mathrm{m}(n=21)$.

\section{Specific myogenic characteristics of obtained CM-like cells}

Generated CM-like single cells exhibit mRNA encoding the general muscle marker cTnT as well as typical ventricular markers such as Myl2 (both more then 2-fold higher expressed compared to control) and Cx43 (Fig. 4A).

Yet, the occurrence of the funny channel Hcn4, specifically expressed in the first heart field (FHF) and cardiac conduction system cells, is an evidence for the still immature phenotype of the cells [2-5]. Notably, thereby Nkx2.5 overexpression led to a significant reduction of Hcn 4 mRNA compared to the control. Thus, $\alpha$ MHC selection engenders a pure $\mathrm{CM}$ cell population and the additional Nkx2.5 overexpression further enhances ventricular maturation. In addition, the cells displayed expression of structural proteins more typical for ventricular CMs ( $\alpha$-actinin, cTnT, Myh6, Myh7) (Fig. 4B). They demonstrate both intertwining filament structures: the thin actin filament and the thick myosin filament; however, only Nkx2.5 overexpressing clones displayed both isoforms, $\alpha$ - and $\beta$-MHC, indicating that these cells correspond to a late fetal developmental stage [41, 42].

Spontaneous beating activity of obtained CM-like cells to verify functional parameters, beating frequencies (Fig. 5) and their response to subtype specific pharmacological substances (Fig. 6A-E) were analyzed in comparison to murine neonatal CMs (mnCM). The majority features a spontaneous beating frequency of $0-426$ beats $\min ^{-1}$. Control cells also showed highly varying beating frequencies (36-378 beats $\min ^{-1}$ ) reflecting their heterogeneous differentiation processes, whereas mnCM $\left(30-174\right.$ beats $\left.\mathrm{min}^{-1}\right)$ were beating at significantly slower rates. Moreover, subdivision into morphological different cell 


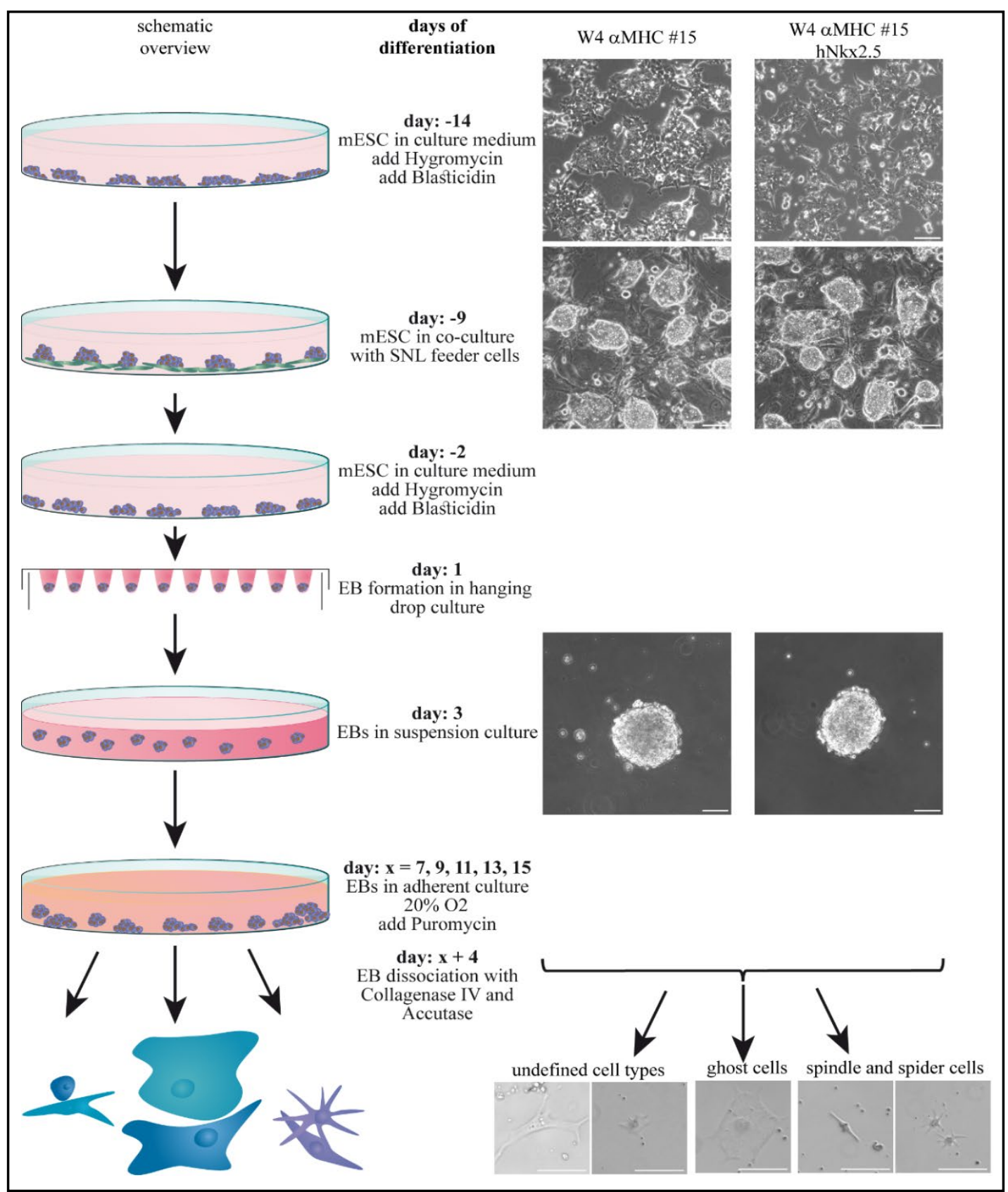

Fig. 3. Cardiogenic differentia-tion protocol of mESCs: Schematic overview of the cardiogenic differentiation protocol and representative cell pictures for murine ES cells using: W4, W4 $\alpha$ MHC and W4 $\alpha$ MHC hNkx2.5 clones. mESCs were cultivated in LIF supplemented medium with appropriate antibiotic pressure (W4 $\alpha$ MHC: hygromycin; W4 $\alpha$ MHC hNkx2.5: hygromycin and blasticidin). Afterwards, cells were co-cultured with mitotically inactivated murine STO cell line-derived SNL 76/7 (73). Prior to differentiation, cells were detached from feeder cells, and subsequently cultured for additional 2 days with appropriate antibiotic pressure. Specific cardiac differentiation was induced through EB formation and subsequent culturing in differentiation medium. $\alpha$ MHC-selection using puromycin was induced at various points in time (day: $\mathrm{x}$ $=7,9,11,13,15)$, respectively. A dissociation step 4 days after selection (day: $x+4$ ) led to the generation of single cells with the following morphogenic classification: spindle and spider like cells, large round and large square cells or an undefined cell population including large longitudinal and small round cells. There are no living cells present in the W4 population after puromycin treatment scale bar: $100 \mu \mathrm{m}$. 


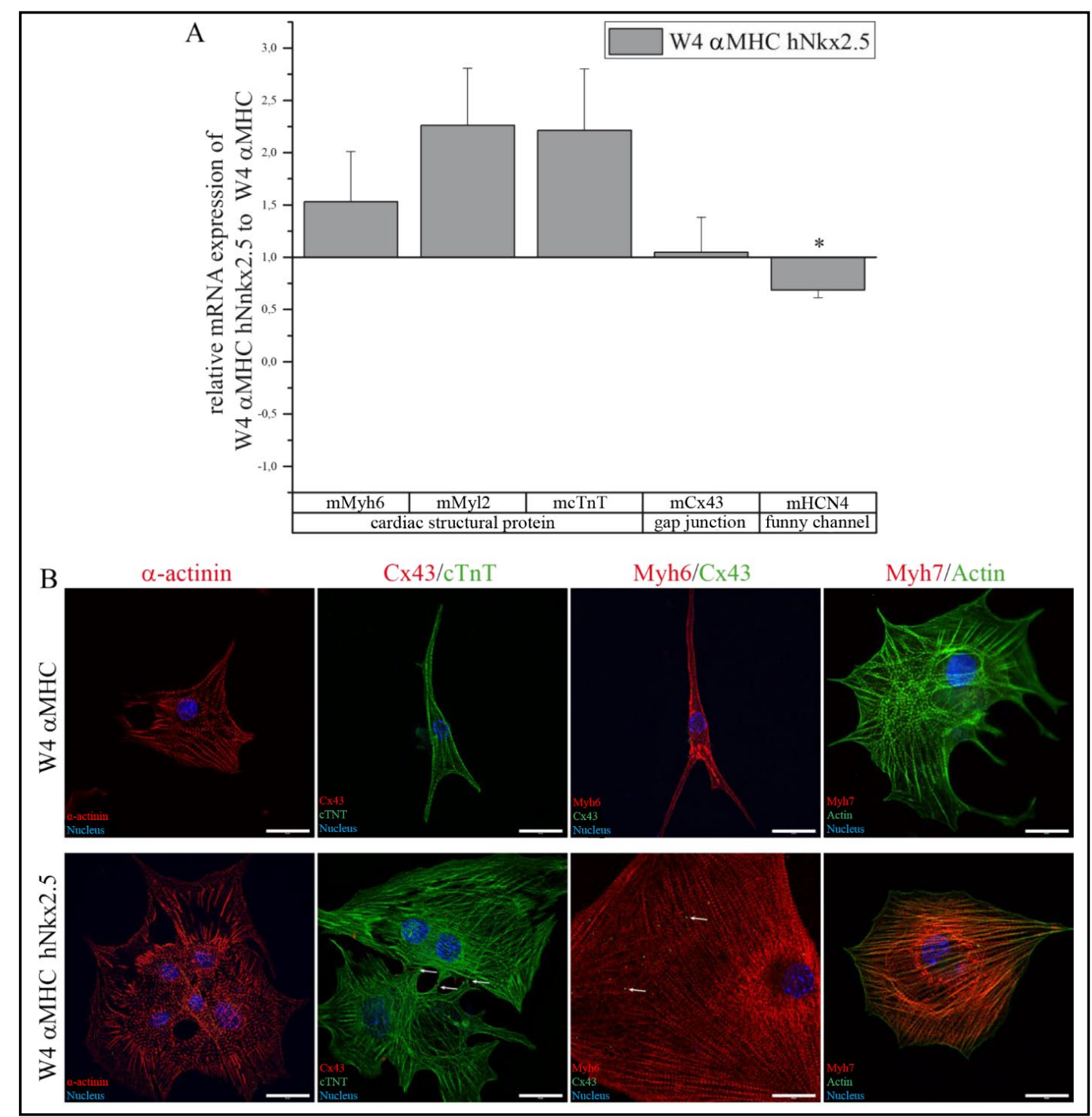

Fig. 4. Cardiogenic marker expression: Analysis of cardiogenic marker expression on mRNA (A) and protein (B) levels by comparison of W4 $\alpha \mathrm{MHC}$ and $\mathrm{W} 4 \alpha \mathrm{MHC}$ hNkx2.5 on day 25 of differentiation. (A) Relative expression of cardiac structural and gap junction proteins as well as funny channel marker performed by qPCR. Values normalized to mHprt and mPolr2a and relativized to W4 $\alpha$ MHC (set: 1). Values are presented as mean \pm SEM; $n=3$; statistic was performed as t-test, ${ }^{*} p \leq 0.05$. (B) Immunostaining of $1: \alpha$-actinin (red) , 2: Cx43 (red, arrow) and cTnT (green), 3: Myh6 (red) and Cx43 (green, arrow) and 4: Myh7 (red) and Actin (green) with counterstaining of nuclei (blue). Scale bar: $20 \mu \mathrm{m}$.

types displayed a significant distinction in beating frequencies (Fig. 5B). The square cells exhibited the slowest average beating frequencies for control as well as Nkx2.5 programmed cells whereby only the latter yielded $\alpha$ MHC promoter-selected CM-like cells which did not contract spontaneously, Overall, the beating frequencies of this group ranged from 0-228 beats $\min ^{-1}$. 


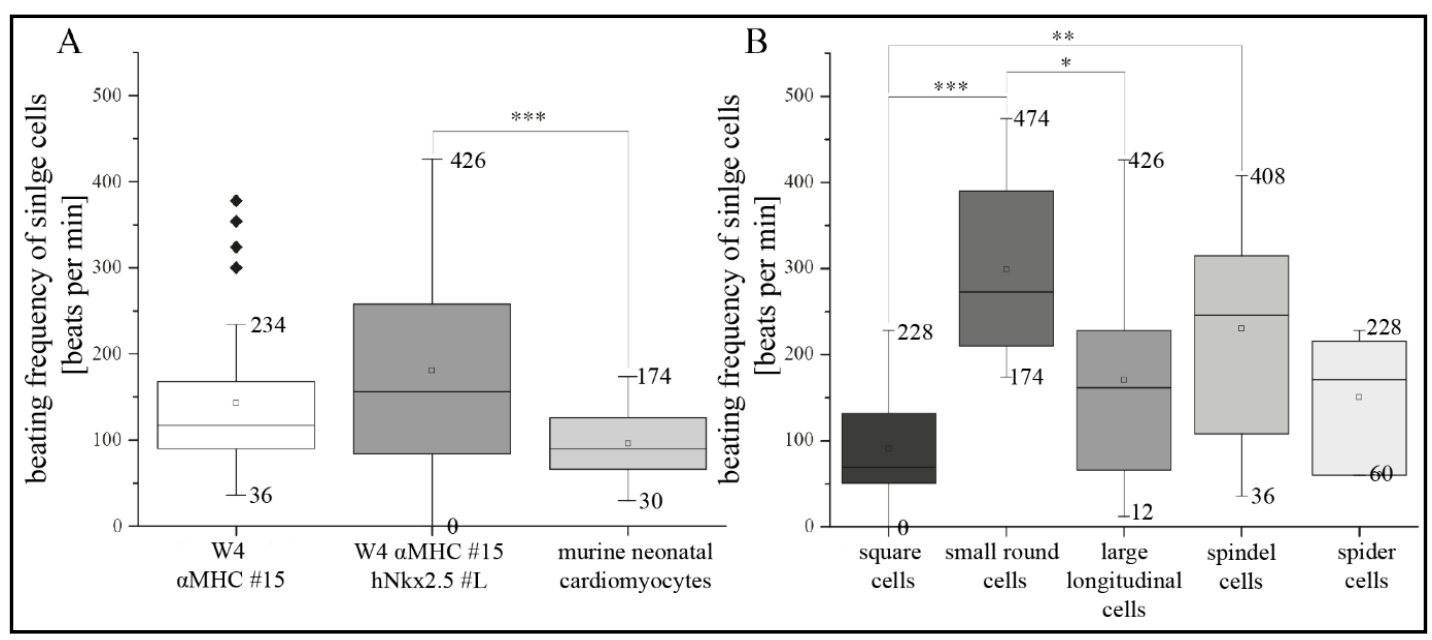

Fig. 5. Beating frequencies of obtained CM-like single cells: Analysis of beating frequencies of CM-like single cells on day 25 of differentiation and murine neonatal cardiomyocytes. (A) Beating frequencies of single cells (excluding small round dying cells) as well as murine neonatal CM and (B) further W4 $\alpha$ MHC hNkx2.5 subdivision on basis of morphological distinction (including small round dying cells) displayed as boxplots, with $25 \%$ - and $75 \%$-quantil, coeff. 1.5, outliers marked, horizontal line indicates media, square indicates mean; $A: n=38,88,32$ and $B: n=16,8,33,16,6$. Statistics were performed as multiple comparison of mean (ANOVA), ${ }^{* * *} \mathrm{p} \leq 0.001$.

\section{Response of CM-like cells on pharmacological substance administration}

Next, we addressed the impact of excitatory $(1 \mu \mathrm{M}$ Noradrenaline, NA) and inhibitory $(10 \mu \mathrm{M}$ Acetylcholine, ACh; $10 \mu \mathrm{M}$ Tetrodotoxin, TTX; $20 \mathrm{mM}$ potassium rich extracellular fluid, $\mathrm{K}^{+} ; 10 \mu \mathrm{M}$ Mibefradil, Mibe; $10 \mu \mathrm{M}$ Verapamil, Vera) pharmacological substance administrations referring to specific ion channel availability (Fig. 6A). A representative depiction of the recording strategy is demonstrated in Fig. $6 \mathrm{~F}$ using a Nkx2.5 programmed single cell under Verapamil administration. It became apparent that CM-like cells derived from the W4 $\alpha \mathrm{MHC}$ clone represent an inconsistent population, reacting to each substance with a large standard deviation. Similarly, also mnCM consist of a heterogeneous population reacting on the one hand moderately significant to Mibefradil, an inhibitor of T-type calcium channels typically expressed in pacemaker cells, as well as highly significant to Verapamil, an inhibitor of L-type calcium channels typically expressed in cells of the contractile system (Fig. 6B-E). A significant difference is obvious in the response to Verapamil, between W4 $\alpha \mathrm{MHC}$ and CM-like cells derived from the Nkx2.5 overexpressing clone as well as between W4 $\alpha \mathrm{MHC}$ and mnCMs (Fig. 6E). Moreover, the latter differ additionally in reaction on Mibefradil. However, the analyzed cells showed only a slight response to essential channel modulators NA, ACh, TTX and $\mathrm{K}^{+}$. Moreover, we observed a complete stop of beating activities at higher concentrations (data not shown). The cells responded significantly to acetylcholine which affects the ligand-dependent muscarinic acetylcholine receptor type M2. In adult hearts, this receptor is abundant in the atria as well as in the sinoatrial- and atrioventricular nodes, where it is involved in vagal regulation of the heart rate $[43,44]$. On the other hand, the response of CM-like cells derived from the Nkx2.5 overexpressing clone argues for an early ventricular subtype as the significant reduction of the beating frequency after application of Verapamil indicates a specific L-type calcium channel occurrence. 


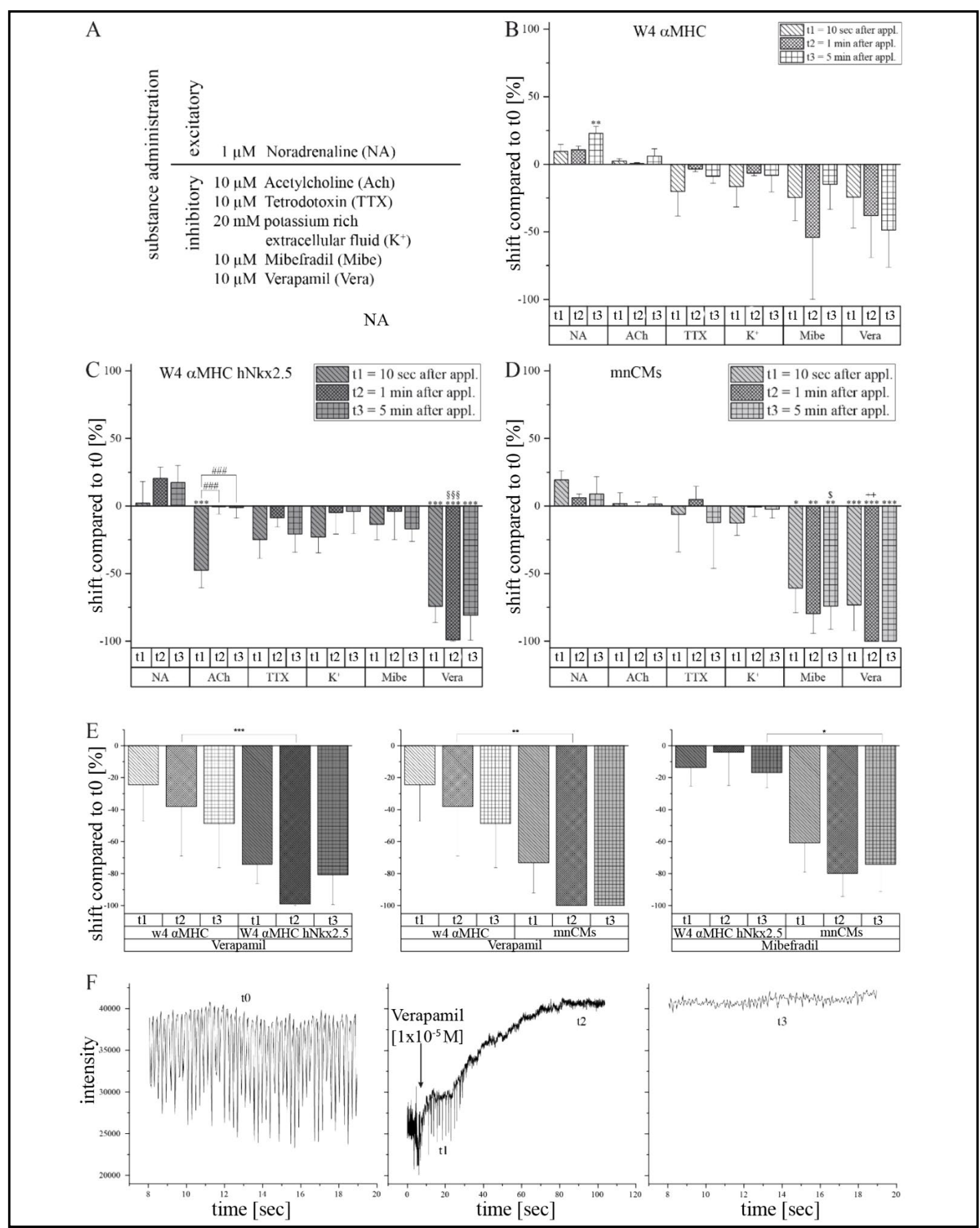

Fig. 6. Response of beating frequencies to pharmacological substance administration: Analysis of beating frequencies after administration of (A) indicated amounts of inhibitory and excitatory pharmacological substances on obtained CM-like single cells of (B) W4 $\alpha \mathrm{MHC}$, (C) W4 $\alpha \mathrm{MHC}$ hNkx2.5 and (D) monolayer murine neonatal cardiomyocytes in relation to baseline frequencies recorded for every individual cell (t0). (E) separate statistical overview of Verapamil and Mibefradil to illustrate significant differences. (F) Representative examples for beating frequencies of a W4 $\alpha \mathrm{MHC} h N \mathrm{kx} 2.5$ programmed single cell before (t0) and after $(\mathrm{t} 1, \mathrm{t} 2, \mathrm{t} 3)$ Verapamil application using ELYRA PS.1 LSM 780 confocal microscope and ZEN2011 software. Values are presented as mean \pm SEM; $n=3-17$; statistics were performed as multiple comparison of mean, $* / \# / \$ \mathrm{p} \leq 0.05,{ }^{* *} / \# \# /++\mathrm{p} \leq 0.01,{ }^{* * *} / \# \# \# / \S \S \S \mathrm{p} \leq 0.001$. ( ${ }^{*}$ : comparison to t0, \#: comparison within all time points (t1, t2, t3), \$: comparison W4 $\alpha$ MHC hNkx2.5 and mnCMs, ++: comparison W4 $\alpha$ MHC and mnCMs, $\S \S \S$ : comparison W4 $\alpha \mathrm{MHC}$ and W4 $\alpha \mathrm{MHC}$ hNkx2.5). 


\section{Cellular Physiology Cell Physiol Biochem 2019;53:337-354 \\ \begin{tabular}{ll|l} 
and Biochemistry & $\begin{array}{l}\text { DOl: 10.33594/000000142 } \\
\text { Published online: } 3 \text { August 2019 }\end{array}$ & $\begin{array}{l}\text { O } 2019 \text { The Author(s). Published by } \\
\text { Cell Physiol Biochem Press GmbH\&Co. KG }\end{array}$ \\
\cline { 2 - 3 }
\end{tabular} \\ Thiele et al.: Nkx2.5 Based Ventricular Programming}

\section{Discussion}

The necessity of continually enhancing the knowledge of molecular and cellular mechanisms underlying cardiovascular development is of great relevance, considering the insufficient therapies for treatment of heart failure. The human heart cannot accomplish a functional repair due to its negligible myocardial regeneration capacity $[45,46]$ after the severe loss of CM e.g. after a myocardial infarction (MI) $[47,48]$. Therefore, a major intention is the regeneration of the myocardium using various approaches, such as cell replacement of the affected tissue. Moreover, the availability of such cells is a crucial prerequisite for novel drug testing approaches in vitro which may allow a significant reduction of animal experiments in the future.

Currently, true terminal cardiac differentiation of PSCs into fully mature CMs is still unfeasible in vitro [49], therefore major efforts should be undertaken to improve purity, yield and safety of physiologically functional PSC-derived CM. In this regard, commercially available PSC-derived CMs, such as murine Cor.At or human Cor.4U as well as human ventricular specific vCor.4U (all Axiogenesis AG, Germany) display indeed a highly pure cardiac population; however, even the latter contain no more than $90 \%$ ventricular cells with remaining $10 \%$ atrial and pacemaker cells as indicated by manual patch clamping using E-4031, a blocker of potassium channels (see the company's website). Overall, these promotor-selected cell populations are merely usable for research and drug development applications due to their arrhythmogenic potential as well as their stably integrated selection cassettes. Therefore, it is of major interest to identify suitable differentiation methodologies and stepwise protocol optimization initially using murine ESCs as proper basis for subsequent translation to more difficult available human cell cultures.

There are clear evidences that an exogenous overexpression of specific cardiac TFs such as Nkx2.5 direct the transition of ESCs toward a ventricular subtype identity [22, 30]. Furthermore, small molecules such as AA promote cardiomyogenesis of PSCs [39], however, further investigations are needed to clarify the underlying mechanisms and the impact of such modulators. Studies demonstrated an impact of AA on epigenetic regulators [50, 51] thereby effecting genes involved in cancer, cellular growth, proliferation and tissue development [52]. In addition, data from Bartsch et al. [53] demonstrate an influence of AA on reactive oxygen species (ROS) and nitric oxide which confirms a ROS and NADPH oxidase mediated stimulation of ESC-derived CM [54]. Further studies confirm this positive effect of AA on cardiac differentiation $[39,40]$.

In order to increase the purity of cardiac programmed cells [30], we included an antibiotic selection step in our protocol, using puromycin resistance under control of the $\alpha$ MHC promotor $[31,34,55]$. Through this, we could improve the protocol from David et al., 2009 from $28 \%$ CM-like cells (with only 22 \% ventricular-like cells in total cell population) to a $100 \%$ pure $\alpha \mathrm{MHC}^{+} \mathrm{CM}$-like population. In addition, Nkx2.5 overexpression supports ventricular maturation. Initially, the optimal time point of selection was evaluated to achieve the best recovery, with the success that a 9.77-fold higher amount of CM-like cells can be achieved using a time point immediately following the suspension culture period. This clearly underlines the fact that the programming factor Nkx2.5 forces differentiating pluripotent cells into cardiomyocytic lineage as shown previously [30].

Our morphological observations indicate an immature phenotype of single cells at day 25 of differentiation. Thereby, large round and large square cells as well as large longitudinal cells rather show similarities to typically round- or polygonal-shaped fetal CM than to elongated mature CM [56], whereas spindle- and spider-like cells resemble previously described single cell morphologies of programmed nodal cells [34]. Moreover, the transition to a binucleate phenotype was not yet initiated. The mononucleated state enables CM growth during early heart development [57] and changes rapidly over a postnatal period of 1-2 weeks in rodents to a non-dividing terminally differentiated binucleate phenotype [58], thus $90 \%$ of adult ventricular CM are binucleated [59]. 
However, the exogenous overexpression of Nkx2.5 indeed directs the cells towards a ventricular subtype, indicated by a better organized sarcomeric structure of myofibrils as well as by gene expression patterns of ventricular specific structural proteins; however, not significantly different to control cells. They demonstrate intertwining filament structures, the thin actin filament as well as two isoforms of thick myosin filaments. Nonetheless, only W4 $\alpha$ MHC hNkx2.5 display distinct striped expression of $\alpha$-myosin as well as $\beta$-myosin in co-localization with actin. The distribution of the ventricular myosin isoforms is temporally regulated during development. Whereas $\alpha-\mathrm{MHC}$ is predominantly expressed in adult hearts and $\beta$-MHC abundant in late fetal development in species like mouse and rat $[41,42,60]$, the distribution is reverted in mammals such as rabbits and pigs: $\alpha$-MHC is only transiently predominantly expressed neonatally and $\beta$-MHC returns after three weeks and is most abundant in adult hearts [60]. Furthermore, adult dogs, cattles and humans express primarily the $\beta$-MHC isoform [60]. Since both isoforms are partially present in our ventricular-like programmed CMs, it can be assumed that these cells are still in a late embryonic stage. In addition, $\alpha$ - and $\beta$ MHC isoforms have a varying impact on actin filament activation through cTnT [61], which also lead to a different calcium sensitivity and heart rates. Moreover, $\alpha$ MHC exhibit a high $\mathrm{Ca}^{2+}$-ATPase activity, whereby $\beta$-MHC exhibit a low $\mathrm{Ca}^{2+}$-ATPase activity [41, $62]$. This and other reasons engender cells with fast cycling $\alpha \mathrm{MHC}$ isoforms [42] which have fast heart rates (650 - $800 \mathrm{bpm}$, [63]) and slow cycling $\beta \mathrm{MHC}$ isoforms [42] which have slow heart rates $(60-120 \mathrm{bpm},[63])$. Thus, subdivision into morphological different populations exhibit a significant difference, whereby large square and large round cells are the slowest population which goes along with the observation of $\beta M H C$ expression detected in this cells. Furthermore, the cells express cardiac specific markers on RNA as well as protein levels [56], thus confirming earlier observations, especially a significant lower expression of the nodal specific funny channel Hcn4 [30].

Since electrophysiological investigations have already been performed with ESC-derived Nkx2.5 overexpressing cells [30], an alternative and supplementary approach, the response to pharmacological substances was examined, addressing the beating frequencies of CM-like cells. Recorded beating frequencies of all cells under investigation (including freshly isolated $\mathrm{mnCM}$ ) are in median considerably slower than mouse heart rates (range between $500-700$ beats $\left.\min ^{-1}\right)[64,65]$ whereby, W4 $\alpha$ MHC Nkx2.5 derived CM-like cells display the broadest range of beating frequencies. Moreover, they seem to possess a calcium channel specification as they respond significantly to the channel antagonist verapamil, a phenylacylamine which inhibits L-type as well as T-type $\mathrm{Ca}^{2+}$-channels [66], leading to a complete stop of beating. This reaction distinguished them with high significance from control cells, which endorse a channel specification triggered by our differentiation procedure.

In addition, they only respond moderately to Mibefradil, an antagonist which is more selective and preferentially blocks T-type $\mathrm{Ca}^{2+}$-channel, 10- to 15-fold [67], predominantly expressed in sinoatrial nodal cells in the adult heart and only functionally expressed during embryonic development [68].

It can therefore be concluded that a forced exogenous overexpression of the early cardiovascular TF Nkx2.5 along with a cardiogenic differentiation and selection protocol does strongly promote ventricular subtype identity.

Although overexpression of Nkx2.5 promotes the development towards a ventricular phenotype the overall yield of our differentiation protocol is still at a quite low level, giving a PSC / CM ratio of 1:0.05 (Fig. 2C, D). In this regard, a comparison of our cell yields with other published protocols is difficult since most studies lack detailed information about the number of input PSCs and obtained CMs. Yet, three groups did report PSC / CM ratios between 1:2 and 1:200 but did not focus on programming of specific cardiac subtypes as the respective papers addressed enhanced cardiac differentiation in general e.g. by using bioreactors [6971]. Transference of our differentiation protocol to similar mass production approaches will be a prerequisite for translational applications of these programming derived subtype CMs.

Murine as well as human PSC derived CMs based on antibiotic selection in large scale bioreactors are already commercially available. However, these generally represent random 


\section{Cellular Physiology Cell Physiol Biochem 2019;53:337-354

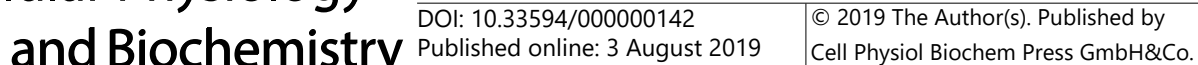 \\ Thiele et al.: Nkx2.5 Based Ventricular Programming}

mixtures of CM subtypes. Therefore, while our data are based on a single murine ES cell line (W4), the approach will likely be rapidly transferable to other murine as well as human iPSC- and ESC-lines. A while ago, we had described generation of pure murine ESC derived pacemaker cells combining human Tbx3 based programming with antibiotic selection [34]. However, applying the Nkx2.5 based programming approach on another transgenic cell line would help to further validate our current differentiation protocol. Therefore, future work will be required to evaluate the applicability of our programming method to other cell culture systems. Ultimately, avoidance of any stably integrating programming as well as selection cassettes is of course highly desirable. In this regard, multiple cardiac differentiation protocols have meanwhile been published [72-74]. It remains to be seen whether an ultimate protocol fully reproducible between labs in the field as well as between different cell lines will emerge. On the other hand, avoidance of stable introduction of programming factor DNA constructs could be achieved via use of modified mRNA or non-integrating viral vectors [72-74].

\section{Acknowledgements}

Author contributions: F.T.: conception and design, collection and/or assembly of data, data analysis and interpretation, manuscript writing; C.V., V.K., H.L.: collection and/ or assembly of data, data analysis and interpretation; P.M., H.L., J.J.J., C.R.: collection and/or assembly of data, G.S., T.N., R.D. and H.L.: conception and design, final approval of manuscript.

All experiments involving neonatal mice were carried out according to the ethical guidelines for animal care of the Rostock University Medical Centre.

This work was supported by the Federal Ministry of Education and Research Germany (FKZ 0312138A and FKZ 316159), the State Mecklenburg-Western Pomerania with EU Structural Funds (ESF/IVWM-B34-0030/10 and ESF/IVBM-B35-0010/12), and the DFG (DA1296/6-1) and the German Heart Foundation (F/01/12). In addition, R.D. and H.L. are supported by the EU structural Fond (ESF/14-BM-A55-0024/18), the FORUN Program of Rostock University Medical Centre (889001 and 889003) and the Josef and Käthe Klinz Foundation (T319/29737/2017). R.D. is supported the DAMP Foundation and the BMBF (VIP+ 00240).

\section{Disclosure Statement}

The authors declare that there is no conflict of interest.

\section{References}

1 Sahara M, Santoro F, Chien KR: Programming and reprogramming a human heart cell. EMBO J 2015;34:710-738.

2 Vincent SD, Buckingham ME: How to make a heart: the origin and regulation of cardiac progenitor cells. Curr Top Dev Biol 2010;90:1-41.

3 Brade T, Pane LS, Moretti A, Chien KR, Laugwitz KL: Embryonic heart progenitors and cardiogenesis. Cold Spring Harb Perspect Med 2013;3:a013847.

4 Später D, Abramczuk MK, Buac K, Zangi L, Stachel MW, Clarke J, Sahara M, Ludwig A, Chien KR: A HCN4+ cardiomyogenic progenitor derived from the first heart field and human pluripotent stem cells. Nat Cell Biol 2013;15:1098-1106.

5 George V, Colombo S, Targoff KL: An early requirement for nkx2.5 ensures the first and second heart field ventricular identity and cardiac function into adulthood. Dev Biol 2015;400:10-22.

6 Cai CL, Liang X, Shi Y, Chu PH, Pfaff SL, Chen J, Evans S: Isl1 Identifies a Cardiac Progenitor Population that Proliferates Prior to Differentiation and Contributes a Majority of Cells to the Heart. Dev Cell 2003;5:877-889. 
7 Dyer LA, Kirby ML: The role of secondary heart field in cardiac development. Dev Biol 2009;336:137144.

8 David R, Brenner C, Stieber J, Schwarz F, Brunner S, Vollmer M, Mentele E, Müller-Höcker J, Kitajima S, Lickert H, Rupp R, Franz WM: MesP1 drives vertebrate cardiovascular differentiation through Dkk-1mediated blockade of Wnt-signalling. Nat Cell Biol 2008;10:338-345.

9 David R, Jarsch VB, Schwarz F, Nathan P, Gegg M, Lickert H, Franz WM: Induction of MesP1 by Brachyury(T) generates the common multipotent cardiovascular stem cell. Cardiovasc Res 2011;92:115122.

10 Bondue A, Tannler S, Chiapparo G, Chabab S, Ramialison M, Paulissen C, Beck B, Harvey R, Blanpain C: Defining the earliest step of cardiovascular progenitor specification during embryonic stem cell differentiation. J Cell Biol 2011;192:751-765.

11 Pradhan L, Gopal S, Li S, Ashur S, Suryanarayanan S, Kasahara H, Nam HJ: Intermolecular Interactions of Cardiac Transcription Factors NKX2.5 and TBX5. Biochemistry 2016;55:1702-1710.

12 Olson EN: Gene regulatory networks in the evolution and development of the heart. Science 2006;313:1922-1927.

13 Sylva M, van den Hoff MJ, Moorman AF: Development of the human heart. Am J Med Genet A 2014;164A:1347-1371.

14 Bodmer R: The gene tinman is required for specification of the heart and visceral muscles in Drosophila. Development 1993;118:719-729.

15 Azpiazu N, Frasch M: tinman and bagpipe: two homeo box genes that determine cell fates in the dorsal mesoderm of Drosophila. Genes Dev 1993;7:1325-1340.

16 Chen JN, Fishman MC: Zebrafish tinman homolog demarcates the heart field and initiates myocardial differentiation. Development 1996;122:3809-3816.

17 Cleaver OB, Patterson KD, Krieg PA: Overexpression of the tinman-related genes XNkx-2.5 and XNkx-2.3 in Xenopus embryos results in myocardial hyperplasia. Development 1996;122:3549-3556.

18 Chaix MA, Andelfinger G, Khairy P: Genetic testing in congenital heart disease: A clinical approach. World J Cardiol 2016;8:180-191.

19 Cowan JR, Ware SM: Genetics and genetic testing in congenital heart disease. Clin Perinatol 2015;42:37393, ix.

20 Balci MM, Akdemir R: NKX2.5 mutations and congenital heart disease: is it a marker of cardiac anomalies? Int J Cardiol 2011;147:e44-45.

21 Xie X, Shi X, Xun X, Rao L: Associations of NKX2-5 Genetic Polymorphisms with the Risk of Congenital Heart Disease: A Meta-analysis. Pediatr Cardiol 2016;37:953-961.

22 Dorn T, Goedel A, Lam JT, Haas J, Tian Q Herrmann F, Bundschu K, Dobreva G, Schiemann M, Dirschinger R, Guo Y, Kuhl SJ, Sinnecker D, Lipp P, Laugwitz KL, Kuhl M, Moretti A: Direct nkx2-5 transcriptional repression of isl1 controls cardiomyocyte subtype identity. Stem Cells 2015;33:1113-1129.

23 Prall OWJ, Menon MK, Solloway MJ, Watanabe Y, Zaffran S, Bajolle F, Biben C, McBride JJ, Robertson BR, Chaulet H, Stennard FA, Wise N, Schaft D, Wolstein O, Furtado MB, Shiratori H, Chien KR, Hamada H, Black BL, Saga Y, et al.: An Nkx2-5/Bmp2/Smad1 negative feedback loop controls heart progenitor specification and proliferation. Cell 2007;128:947-959.

24 Segers VFM, Lee RT: Stem-cell therapy for cardiac disease. Nature 2008;451:937-942.

25 Okano H, Nakamura M, Yoshida K, Okada Y, Tsuji O, Nori S, Ikeda E, Yamanaka S, Miura K: Steps toward safe cell therapy using induced pluripotent stem cells. Circ Res 2013;112:523-533.

26 Chong, James J H, Yang X, Don CW, Minami E, Liu YW, Weyers JJ, Mahoney WM, van Biber B, Cook SM, Palpant NJ, Gantz JA, Fugate JA, Muskheli V, Gough GM, Vogel KW, Astley CA, Hotchkiss CE, Baldessari A, Pabon L, et al:. Human embryonic-stem-cell-derived cardiomyocytes regenerate non-human primate hearts. Nature 2014;510:273-277.

27 Laurent LC, Ulitsky I, Slavin I, Tran H, Schork A, Morey R, Lynch C, Harness JV, Lee S, Barrero MJ, Ku S, Martynova M, Semechkin R, Galat V, Gottesfeld J, Izpisua Belmonte, Juan Carlos, Murry C, Keirstead HS, Park HS, et al.: Dynamic changes in the copy number of pluripotency and cell proliferation genes in human ESCs and iPSCs during reprogramming and time in culture. Cell Stem Cell 2011;8:106-118.

28 Newman AM, Cooper JB: Lab-specific gene expression signatures in pluripotent stem cells. Cell Stem Cell 2010;7:258-262.

29 Narsinh KH, Sun N, Sanchez-Freire V, Lee AS, Almeida P, Hu S, Jan T, Wilson KD, Leong D, Rosenberg J, Yao M, Robbins RC, Wu JC: Single cell transcriptional profiling reveals heterogeneity of human induced pluripotent stem cells. J Clin Invest 2011;121:1217-1221. 


\section{Cellular Physiology Cell Physiol Biochem 2019;53:337-354 and Biochemistry DOl: 10.33594/000000142 2019 2019 The Author(s). Published by and BiOChemistry Published online: 3 August 2019 Cell Physiol Biochem Press GmbH\&Co. KG \\ Thiele et al.: Nkx2.5 Based Ventricular Programming}

30 David R, Stieber J, Fischer E, Brunner S, Brenner C, Pfeiler S, Schwarz F, Franz WM: Forward programming of pluripotent stem cells towards distinct cardiovascular cell types. Cardiovasc Res 2009;84:263-272.

31 Klug MG, Soonpaa MH, Koh GY, Field LJ: Genetically selected cardiomyocytes from differentiating embronic stem cells form stable intracardiac grafts. J Clin Invest 1996;98:216-224.

32 Auerbach W, Dunmore JH, Fairchild-Huntress V, Fang Q, Auerbach AB, Huszar D, Joyner AL: Establishment and chimera analysis of $129 / \mathrm{SvEv}$ - and C57BL/6-derived mouse embryonic stem cell lines. BioTechniques 200029: 1024-1028, 1030, 1032.

33 Rimmbach C, Jung JJ, David R: Generation of murine cardiac pacemaker cell aggregates based on ES-cellprogramming in combination with Myh6-promoter-selection. J Vis Exp 2015; DOI:10.3791/52465.

34 Jung JJ, Husse B, Rimmbach C, Krebs S, Stieber J, Steinhoff G, Dendorfer A, Franz WM, David R: Programming and isolation of highly pure physiologically and pharmacologically functional sinus-nodal bodies from pluripotent stem cells. Stem Cell Reports 2014;2:592-605.

35 Lemcke H, Peukert J, Voronina N, Skorska A, Steinhoff G, David R: Applying 3D-FRAP microscopy to analyse gap junction-dependent shuttling of small antisense RNAs between cardiomyocytes. J Mol Cell Cardiol 2016;98:117-127.

36 Morgani SM, Brickman JM: LIF supports primitive endoderm expansion during pre-implantation development. Development 2015;142:3488-3499.

37 Ohtsuka S, Nakai-Futatsugi Y, Niwa H: LIF signal in mouse embryonic stem cells. JAKSTAT 2015;4:e1086520.

38 Park YG, Lee SE, Kim EY, Hyun H, Shin MY, Son YJ, Kim SY, Park SP: Effects of Feeder Cell Types on Culture of Mouse Embryonic Stem Cell In Vitro. Dev Reprod 2015;19:119-126.

39 Ivanyuk D, Budash G, Zheng Y, Gaspar JA, Chaudhari U, Fatima A, Bahmanpour S, Grin VK, Popandopulo AG, Sachinidis A, Hescheler J, Saric T: Ascorbic Acid-Induced Cardiac Differentiation of Murine Pluripotent Stem Cells: Transcriptional Profiling and Effect of a Small Molecule Synergist of Wnt/betaCatenin Signaling Pathway. Cell Physiol Biochem 2015;36:810-830.

40 Takahashi T, Lord B, Schulze PC, Fryer RM, Sarang SS, Gullans SR, Lee RT: Ascorbic acid enhances differentiation of embryonic stem cells into cardiac myocytes. Circulation 2003;107:1912-1916.

41 Mahdavi V, Chambers AP, Nadal-Ginard B: Cardiac alpha- and beta-myosin heavy chain genes are organized in tandem. Proc Natl Acad Sci U S A 1984;81:2626-2630.

42 Nadal-Ginard B, Mahdavi V: Expression of the cardiac ventricular alpha- and beta-myosin heavy chain genes is developmentally and hormonally regulated. J Biol Chem 1984;259:6437-6446.

43 Nenasheva TA, Neary M, Mashanov GI, Birdsall NJM, Breckenridge RA, Molloy JE: Abundance, distribution, mobility and oligomeric state of M(2) muscarinic acetylcholine receptors in live cardiac muscle. J Mol Cell Cardiol 2013;57:129-136.

44 Haga K, Kruse AC, Asada H, Yurugi-Kobayashi T, Shiroishi M, Zhang C, Weis WI, Okada T, Kobilka BK, Haga T, Kobayashi T: Structure of the human M2 muscarinic acetylcholine receptor bound to an antagonist. Nature 2012;482:547-551.

45 Bergmann O, Bhardwaj RD, Bernard S, Zdunek S, Barnabe-Heider F, Walsh S, Zupicich J, Alkass K, Buchholz BA, Druid H, Jovinge S, Frisen J: Evidence for Cardiomyocyte Renewal in Humans. Science 2009;324:98-102.

46 Mollova M, Bersell K, Walsh S, Savla J, Das LT, Park SY, Silberstein LE, Dos Remedios, Cristobal G, Graham D, Colan S, Kühn B: Cardiomyocyte proliferation contributes to heart growth in young humans. Proc Natl Acad Sci U S A 2013;110:1446-1451.

47 Murry CE, Reinecke H, Pabon LM: Regeneration gaps: observations on stem cells and cardiac repair. J Am Coll Cardiol 2006;47:1777-1785.

48 Laflamme MA, Murry CE: Regenerating the heart. Nat Biotechnol 2005;23:845-856.

49 Veerman CC, Kosmidis G, Mummery CL, Casini S, Verkerk AO, Bellin M: Immaturity of human stem-cellderived cardiomyocytes in culture: fatal flaw or soluble problem? Stem Cells Dev 2015;24:1035-1052.

50 Young JI, Zuchner S, Wang G: Regulation of the Epigenome by Vitamin C. Annu Rev Nutr 2015;35:545564.

51 Blaschke K, Ebata KT, Karimi MM, Zepeda-Martinez JA, Goyal P, Mahapatra S, Tam A, Laird DJ, Hirst M, Rao A, Lorincz MC, Ramalho-Santos M: Vitamin C induces Tet-dependent DNA demethylation and a blastocyst-like state in ES cells. Nature 2013;500:222-226.

52 Camarena V, Wang G: The epigenetic role of vitamin C in health and disease. Cell Mol Life Sci 2016;73:1645-1658. 


\section{Cellular Physiology Cell Physiol Biochem 2019;53:337-354

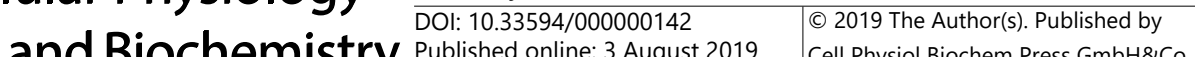 and BiOChemistry Published online: 3 August 2019 Cell Physiol Biochem Press GmbH\&Co. KG \\ Thiele et al.: Nkx2.5 Based Ventricular Programming}

53 Bartsch C, Bekhite MM, Wolheim A, Richter M, Ruhe C, Wissuwa B, Marciniak A, Muller J, Heller R, Figulla HR, Sauer H, Wartenberg M: NADPH oxidase and eNOS control cardiomyogenesis in mouse embryonic stem cells on ascorbic acid treatment. Free Radic Biol Med 2011;51:432-443.

54 Buggisch M, Ateghang B, Ruhe C, Strobel C, Lange S, Wartenberg M, Sauer H: Stimulation of ES-cellderived cardiomyogenesis and neonatal cardiac cell proliferation by reactive oxygen species and NADPH oxidase. J Cell Sci 2007;120:885-894.

55 Bugorsky R, Perriard JC, Vassalli G: Genetic selection system allowing monitoring of myofibrillogenesis in living cardiomyocytes derived from mouse embryonic stem cells. Eur J Histochem 2008;52:1-10.

56 Bird SD, Doevendans PA, van Rooijen MA, La Brutel de Riviere A, Hassink RJ, Passier R, Mummery CL: The human adult cardiomyocyte phenotype. Cardiovasc Res 2003;58:423-434.

57 Paradis AN, Gay MS, Zhang L: Binucleation of cardiomyocytes: the transition from a proliferative to a terminally differentiated state. Drug Discov Today 2014;19:602-609.

58 Li F, Wang X, Capasso JM, Gerdes AM: Rapid transition of cardiac myocytes from hyperplasia to hypertrophy during postnatal development. J Mol Cell Cardiol 1996;28:1737-1746.

59 Liu Z, Yue S, Chen X, Kubin T, Braun T: Regulation of cardiomyocyte polyploidy and multinucleation by CyclinG1. Circ Res 2010;106:1498-1506.

60 Mercadier JJ, Wisnewsky C, Bouveret P, Pantaloni C, D’Albis A, Schwartz K: Species- and age-dependent changes in the relative amounts of cardiac myosin isoenzymes in mammals. Dev Biol 1981;84:286-290.

61 Mamidi R, Mallampalli SL, Wieczorek DF, Chandra M: Identification of two new regions in the $\mathrm{N}$-terminus of cardiac troponin $\mathrm{T}$ that have divergent effects on cardiac contractile function. J Physiol 2013;591:1217-1234.

62 Zot AS, Potter JD: Structural aspects of troponin-tropomyosin regulation of skeletal muscle contraction. Annu Rev Biophys Biophys Chem 1987;16:535-559.

63 Ford SJ, Chandra M: The effects of slow skeletal troponin I expression in the murine myocardium are influenced by development-related shifts in myosin heavy chain isoform. J Physiol 2012;590:6047-6063.

64 Ho D, Zhao X, Gao S, Hong C, Vatner DE, Vatner SF: Heart Rate and Electrocardiography Monitoring in Mice. Curr Protoc Mouse Biol 2011;1:123-139.

65 Thireau J, Zhang BL, Poisson D, Babuty D: Heart rate variability in mice: a theoretical and practical guide. Exp Physiol 2008;93:83-94.

66 Bergson P, Lipkind G, Lee SP, Duban M-E, Hanck DA: Verapamil block of T-type calcium channels. Mol Pharmacol 2011;79:411-419.

67 Martin RL, Lee JH, Cribbs LL, Perez-Reyes E, Hanck DA: Mibefradil block of cloned T-type calcium channels. J Pharmacol Exp Ther 2000;295:302-308.

68 Ono K, Iijima T: Cardiac T-type Ca(2+) channels in the heart. J Mol Cell Cardiol 2010;48:65-70.

69 Chen VC, Ye J, Shukla P, Hua G, Chen D, Lin Z, Liu JC, Chai J, Gold J, Wu J, Hsu D, Couture LA: Development of a scalable suspension culture for cardiac differentiation from human pluripotent stem cells. Stem Cell Res 2015;15:365-375.

70 Ojala M, Rajala K, Pekkanen-Mattila M, Miettinen M, Huhtala H, Aalto-Setala K: Culture conditions affect cardiac differentiation potential of human pluripotent stem cells. PLoS One 2012;7:e48659.

71 Uosaki H, Magadum A, Seo K, Fukushima H, Takeuchi A, Nakagawa Y, Moyes KW, Narazaki G, Kuwahara K, Laflamme M, Matsuoka S, Nakatsuji N, Nakao K, Kwon C, Kass DA, Engel FB, Yamashita JK: Identification of chemicals inducing cardiomyocyte proliferation in developmental stage-specific manner with pluripotent stem cells. Circ Cardiovasc Genet 2013;6:624-633.

72 Hausburg F, Jung JJ, David R: Specific Cell (Re-)Programming: Approaches and Perspectives. Adv Biochem Eng Biotechnol 2018;163:71-115.

73 Hausburg F, Jung JJ, Hoch M, Wolfien M, Yavari A, Rimmbach C, David R: (Re-)programming of subtype specific cardiomyocytes. Adv Drug Deliv Rev 2017;120:142-167.

74 Hausburg F, Naß S, Voronina N, Skorska A, Müller P, Steinhoff G, David R: Defining optimized properties of modified mRNA to enhance virus- and DNA- independent protein expression in adult stem cells and fibroblasts. Cell Physiol Biochem 2015;35:1360-1371. 